\title{
ANALYSIS OF MORBIDITY AND DISABILITY AMONG CHILDREN IN THE CITY OF POLTAVA
}

D0I: 10.36740/WLek202006142

\author{
Inna V. Bielikova, Tatiana V. Pluzhnikova, Oksana I. Krasnova, Iryna N. Zviagolska, Tetyana V. Derev'yanko \\ UKRAINIAN MEDICAL STOMATOLOGICAL ACADEMY, POLTAVA, UKRAINE
}

\begin{abstract}
The aim: analyze the morbidity and causes of disability among children of Poltava.

Materials and methods: medical and statistical - for the collection, processing and analysis of data (descriptive and analytical statistics to determine relative indicators, absolute growth indicators), a systems approach and system analysis. The work uses materials from the State Statistics Service of Ukraine, as well as data from children's hospitals of Poltava. Review: In recent decades, the morbidity and prevalence of diseases of children's of Ukraine remained as high. In the Poltava region, the basis of medical work on the sector includes the principles of early access to medical care, early diagnosis, timely examination and adequate treatment. Over the past five years, there is a decrease in the number of newborns who visited outpatient hospitals. In the structure of causes of childhood disability over the past 5 years, the first three places are occupied by congenital malformations, diseases of the nervous system and diseases of the endocrine system. Moreover, children's disability from diseases of the nervous and endocrine systems is constantly growing. Conclusions: One way to improve the health care system for children is to optimize it. It is aimed at improving preventive work, preserving and restoring the health of the child population, improving and updating medical institutions, and increasing the level of professionalism of medical workers.
\end{abstract}

KEY WORDS: reforming, children, morbidity, disability

Wiad Lek. 2020;73(6):1296-1298

\section{INTRODUCTION}

The World Health Organization has identified that perinatal morbidity and mortality rates are considered as an indicator of the socioeconomic well-being of the nation [1]. The preservation and maintenance of children 's health is a key task and an important condition for the successful economic development of the state, and the protection of children's health is one of the urgent and most significant problems of the healthcare system, the state and society, since the health of the child population is not only an integral indicator of the quality of children's health, but also it is one of the fundamental basis for the formation of the health potential of adult members of the society. Children's health determines the condition of human health in the future, its activity, creative longevity, and therefore the problems of protecting children's health should have the constant attention of the country's government [2]. As a part of the reorganization in prenatal care in Ukraine, it is implemented as the National Project "New Life - New Quality of Maternity and Childhood Protection", the goal of which is to provide the population with affordable, highly qualified medical care, comfortable conditions for the birth and care of the children, and the proper quality of the pediatric service in the context of reform [3]. The medical community has developed different ways for achieve the goal through the implementation of the main components of prenatal care.

\section{THE AIM}

Analyze the morbidity and causes of disability among children the city of Poltava.

\section{MATERIALS AND METHODS}

Medical and statistical - for the collection, processing and analysis of data (descriptive and analytical statistics to determine relative indicators, absolute growth indicators), a systems approach and system analysis. The work uses materials from the State Statistics Service of Ukraine, as well as data from children's hospitals of Poltava.

\section{REVIEW AND DISCUSSION}

According to the State Statistics Service, in Ukraine live about 7600000 children under the age of 17 , and it includes 394 thousand of children of the first year of life. Since 2009, the child population has declined every year due to the low birth rate. Against the background of an unfavorable demographic situation, the state of health of the newborns remains unsatisfactory [4].

In recent decades, the morbidity and prevalence of diseases remained as high. Every sixth to seventh newborn has deviations in health status, in recent years. After birth, the number of sick children is increased. This situation makes necessity to strengthen the preventive orientation of the pediatric service in the terms of both formation, preservation and strengthening the health of the younger generation [5].

The existing information support system does not allow to sufficiently assesse the fulfillment of the tasks assigned to health care institutions for outpatient care of the child population. The accessibility and quality of medical care 
Table I. Organization of preventive care for children of the 1st year of life in the outpatient service of Poltava

\begin{tabular}{cccccc}
\hline Incidence / Years & $\mathbf{2 0 1 4}$ & $\mathbf{2 0 1 5}$ & $\mathbf{2 0 1 6}$ & $\mathbf{2 0 1 7}$ & $\mathbf{2 0 1 8}$ \\
\hline Total newborns were admitted to the clinic & 3133 & 3510 & 3201 & 3002 & 2784 \\
\hline Timeliness of primary patronage of newborns & $100 \%$ & $100 \%$ & $100 \%$ & $100 \%$ & $100 \%$ \\
\hline Review of specialists (\% of the need) & $99,2 \%$ & $99,4 \%$ & $99 \%$ & $95 \%$ & $97 \%$ \\
\hline Laboratory research (\% of need) & $98 \%$ & $98 \%$ & $98 \%$ & $97 \%$ & $97 \%$ \\
\hline The total incidence of children of 1 year of life per 1000 children & 1149,7 & 1068,3 & 1191,5 & 1359,5 & 1356,5 \\
\hline Body Mass Index (BMI) for 1 year old children & 23,2 & 23,5 & 23,5 & 23,4 & 23,2 \\
\hline
\end{tabular}

Table II. The structure of the incidence of children of the 1 st year of life over the past 5 years of Poltava

\begin{tabular}{cccccc}
\hline Incidence / Years & $\mathbf{2 0 1 4}$ & $\mathbf{2 0 1 5}$ & $\mathbf{2 0 1 6}$ & $\mathbf{2 0 1 7}$ & $\mathbf{2 0 1 8}$ \\
\hline Respiratory diseases & $22,5 \%$ & $23,4 \%$ & $28 \%$ & $28,7 \%$ & $31,2 \%$ \\
\hline Skin diseases & $9,8 \%$ & $11,5 \%$ & $10,5 \%$ & $10.7 \%$ & $11,4 \%$ \\
\hline Prenatal pathology & $8,2 \%$ & $8,1 \%$ & $8,8 \%$ & $8,3 \%$ & $7,4 \%$ \\
\hline
\end{tabular}

Table III. The structure of the overall incidence of children over the past 5 years

\begin{tabular}{cccccc}
\hline Incidence / Years & $\mathbf{2 0 1 4}$ & $\mathbf{2 0 1 5}$ & $\mathbf{2 0 1 6}$ & $\mathbf{2 0 1 7}$ & $\mathbf{2 0 1 8}$ \\
\hline Respiratory diseases & $66 \%$ & $65 \%$ & $66 \%$ & $62,8 \%$ & $63,4 \%$ \\
\hline Skin diseases & $6,4 \%$ & $6,7 \%$ & $6,9 \%$ & $6,0 \%$ & $6,1 \%$ \\
\hline Infectious and parasitic diseases & $6,2 \%$ & $6,3 \%$ & $6,9 \%$ & $5,3 \%$ & $4,6 \%$ \\
\hline
\end{tabular}

Table IV. The structure of the causes of childhood disability over the past 5 years

\begin{tabular}{cccccc}
\hline Incidence / Years & $\mathbf{2 0 1 4}$ & $\mathbf{2 0 1 5}$ & $\mathbf{2 0 1 6}$ & $\mathbf{2 0 1 7}$ & $\mathbf{2 0 1 8}$ \\
\hline Congenital malformations & $40,1 \%$ & $38 \%$ & $36,8 \%$ & $35 \%$ & $34,3 \%$ \\
\hline Diseases of the nervous system & $17 \%$ & $17,1 \%$ & $17,6 \%$ & $17,8 \%$ & $18,2 \%$ \\
\hline Endocrine system diseases & $11.1 \%$ & $12.9 \%$ & $14 \%$ & $14,5 \%$ & $15,1 \%$ \\
\hline
\end{tabular}

for children in the prehospital phase is analyzed by the main indicators: the number of children who visited doctors in outpatient facilities and at home, the frequency of breastfeeding of children up to 4 and 6 months of life, preventive examinations with the dynamics of the identified pathology, the level of hospitalization for in-patients. The criteria for accessibility and quality of care system include the number of visits per disease that was registered. In total, for one registered disease among the general child population is accounted for 3,47 visits $[6,7]$.

In Poltava region, the basis of medical work in the sector include all the principles of early access to medical care, early diagnosis, timely examination and adequate treatment. The local pediatric service of Poltava adjourned to the communal enterprise of primary health care № 1,2,3. In the ambulatory of general practice of family medicine, 57 pediatric sectors function. The staffing of pediatrician's district is $82 \%$, while $21 \%$ of working doctors are pensioners. The number of sectors nurses is $98 \%$, while $16 \%$ of them are pensioners [8]. Staffing by doctors of preschool and school institutions is $73 \%$, despite the fact that $45.5 \%$ of employees are pensioners. The staffing level of nurses for preschool and school institutions is $85 \%$ (24,2\% are pensioners). The average number of children on the sector is 865 , including up to 1 year 48 children [8].

In Poltava region over the past five years, there is a decrease in the number of newborns who visited outpatient hospitals, which in its turn leads to a decrease in the percentage of specialist examinations, as well as laboratory tests (Table I.).

In the city of Poltava, in the structure of the general morbidity of children in their first year of life over the past 5 years, respiratory diseases take the first place, skin diseases take the second place, prenatal pathology has the third place (Table II). The increase in the morbidity of children in the1st year of life is associated with increase in the level of hospitalization of children in inpatient units of Poltava region.

In the structure of the general morbidity, the first place is taken by respiratory diseases which has a tendency to decrease in indicators due to a decrease in the morbidity of chickenpox, whooping cough, gastroenterocolitis (Table III).

In children's hospitals and family ambulant clinics in Poltava, children with disabilities under the age of 18 are registered [8]. In the structure of causes of childhood disability over the past 5 years, the first three places are occupied by congenital malformations, diseases of the nervous system and diseases of the endocrine system. Moreover, children's disability from diseases of the nervous and endocrine systems is constantly growing (Table. IV).

A decrease in the number of children with primary access to disability due to diseases, in the structure of the 
Table V. The structure of primary disability among children over the past 5 years

\begin{tabular}{cccccc}
\hline Incidence / Years & $\mathbf{2 0 1 4}$ & $\mathbf{2 0 1 5}$ & $\mathbf{2 0 1 6}$ & $\mathbf{2 0 1 7}$ & $\mathbf{2 0 1 8}$ \\
\hline Congenital malformations & $27,7 \%$ & $25,7 \%$ & $24.7 \%$ & $20 \%$ & $20 \%$ \\
\hline Endocrine system diseases & $24,1 \%$ & $22,7 \%$ & $23,5 \%$ & $20 \%$ & $21.1 \%$ \\
\hline Diseases of the nervous system & $20 \%$ & $18,8 \%$ & $13,5 \%$ & $10,9 \%$ & $8,8 \%$ \\
\hline
\end{tabular}

primary access to disability among the child population, was recorded, occupying the first three places in the structure (Tab. V).

\section{CONCLUSIONS}

We can say, that one of the ways to improve the system of medical care for children is to optimize it. It is aimed at ensuring the availability and quality of medical care, matching its volumes and types to the needs of the child population. The foreground task of the national child health service remains to improve preventive work by gradually reorienting the activities of institutions to primary health care, preserving and reinstating the health of the child population, completing tasks to ensure the harmonious development of the child, and reducing morbidity, disability, and mortality. Modernization involves the process of improving and updating healthcare facilities, bringing them in the conformity with new requirements, standards, specifications, quality indicators and the level of professionalism of medical workers.

In Poltava region, modern technologies for diagnosing and treating childhood diseases are consistently introduced, the latest treatment standards are developing, and the equipment of children's medical institutions and university clinics is improving.

\section{REFERENCES}

1. Pluzhnikova T.V.., Krasnova 0.I., Kasinets S.S. et al. Analysis of morbidity and causes of infant mortality in Poltava. Wiad. Lek. 2019;5:p. 10361140.

2. Znamenska T.K., Nikulina L.I., Rudenko N.H. et al. Analiz roboty perynatalnykh tsentriv u vykhodzhuvanni peredchasno narodzhenykh ditei v Ukraini. [Analysis of the work of perinatal centers in the emergence of premature births in Ukraine]. Neonatology, Surgery and Perinatal Medicine. 2017; 7(2)24: 5-11. (UA)

3. Slabkyi H.0., Dudina 0.0., Haborets Yu.Yu. Rehionalizatsiia perynatalnoi dopomohy - vazhlyvyi chynnyk zabezpechennia natsionalnoi bezpeky krainy. [Regionalization of perinatal care is an important factor in ensuring national security]. Ukraina. Zdorov'ia natsii. 2016; 4(1) : 196204. (UA)

4. Pasiieshvili N.M. Analiz perynatalnoi zakhvoriuvanosti ta smertnosti v umovakh perynatalnoho tsentru ta shliakhy yii znyzhennia. [Analysis of perinatal morbidity and mortality in the perinatal center and ways of its reduction] ScienceRise. Medical science. 2016; 1(3): 37-43 (UA).

5. Pluzhnlkova T.V., Kostrlkov A.V. Analiz poshyrenosti ta zakhvoriuvanosti na osnovni klasy khvorob u naselennia Poltavkoi oblasti ta v Ukraini (2006-2015 rr.) [Analysis of the prevalence and incidence of the main classes of ailments among the population of Poltava region and in Ukraine (2006-2015 pp.)]. Actual problems of modern medicine. 2017; $17(3) 59: 153-156$. (UA)
6. Demografiya y` social’na staty`sty`ka. Oxorona zdorovya. Derzhavna sluzhba staty 'sty 'ky' Ukrayiny'. [Demography and social statistics. Health care. State Statistics Service of Ukraine], 2019. doi: http//ukrstat. org. (UA)

7. Shorichna dopovid' pro stan zdorov'ya naselennya, sanitarnoepidemichnu situaciyu ta rezul'tati diyal'nosti sistemi ohoroni zdorov'ya Ukraini. [Annual report on the state of health of the population, the sanitary-epidemic situation and the results of activity of the health care system of Ukraine]. 2016 rik / za red. 0. S. Musiya. K., 2017. p. 438 (UA)

8. Poltava Regional Information and Analytical Center for Medical Statistics. Directory of indicators of the activities of medical and prophylactic institutions of the region. 2019. Retrieved doi: http://oiacms.poltava. ua. (UA)

The work is a fragment of SRR "Medical and social rationale for optimizing approaches to managing and organizing various types of medical care for adults and children in the period of reforming the health care industry" (№ St. Registered 0119 U102926 term of performance 2018-2022 year)

\section{ORCID and contributorship:}

Inna V. Bielikova - 0000-0002-0104-3083 ${ }^{A, F}$

Tatiana V. Pluzhnikova - 0000-0001-8300-854X C,D

Oksana I. Krasnova - 0000-0001-9819-1818 ${ }^{B, D}$

Iryna N. Zviagolska - 0000-0001-7531-3966 ${ }^{B, E}$

Tetyana V. Derev'yanko - 0000-0002-5097-8299 ${ }^{B, D}$

\section{Conflict of interest:}

The Authors declare no conflict of interest.

\section{CORRESPONDING AUTHOR}

\section{Oksana I. Krasnova}

Ukrainian Medical Stomatological Academy

st. Shevchenko 23, 36000 Poltava, Ukraine

tel: +380984673750

e-mail:krasnovaoksana197@gmail.com

Received: 22.02 .2020

Accepted: 30.04 .2020 